\title{
A Research Agenda for the Future of Ecological Economics by Emerging Scholars
}

\author{
Kaitlin Kish ${ }^{1, *(D)}$ and Joshua Farley ${ }^{2}$ \\ 1 Natural Resource Sciences, McGill University, Montréal, QC H3A 0G4, Canada \\ 2 Gund Institute, University of Vermont, Burlington, VT 05405, USA; jfarley@uvm.edu \\ * Correspondence: kaitlin.kish@mail.mcgill.ca
}

\section{check for}

updates

Citation: Kish, K.; Farley, J.

A Research Agenda for the Future of Ecological Economics by Emerging

Scholars. Sustainability 2021, 13, 1557.

https://doi.org/10.3390/su13031557

Academic Editor: Carlos

Rodríguez Monroy

Received: 15 December 2020

Accepted: 29 January 2021

Published: 2 February 2021

Publisher's Note: MDPI stays neutral with regard to jurisdictional claims in published maps and institutional affiliations.

Copyright: (c) 2021 by the authors. Licensee MDPI, Basel, Switzerland. This article is an open access article distributed under the terms and conditions of the Creative Commons Attribution (CC BY) license (https:// creativecommons.org/licenses/by/ $4.0 /)$.

\begin{abstract}
As a discipline, ecological economics is at a turning point and there is a need to develop a new research agenda for ecological economics that will contribute to the creation and adoption of new economic institutions. There are still considerable environmental issues and a new generation of scholars ready to tackle them. In this paper and Special Issue, we highlight the voices of emerging scholars in ecological economics who put social justice squarely at the center of ecological economic research. The papers in this issue remain true to the central focus of economic downscaling while calling for greater emphasis on culture and society. We acknowledge that methodological and intellectual pluralism inherently entail tensions but strive to find shared normative foundations to collectively work toward socio-ecological transformations. In this editorial, we emphasize the need for further attention to social aspects of ecological economics and evolutionary approaches to further strengthen cooperation.
\end{abstract}

Keywords: ecological economics; evolution; social ecological economics; research agenda; pluralism

\section{Introduction: Motivation for This Special Issue}

Motivation for this Special Issue emerges from the need to develop and adopt new economic institutions that are both socially just and ecologically sustainable [1-6]. While it is impossible to predict novel technological solutions to our challenges or to understand precisely how and when ecosystems will respond to impacts of our current system [7], we believe that degrowth $[8,9]$ toward an Ecozoic era is the most hopeful path towards a sustainable, just, and desirable future [10,11]. Ecological economics is one of the first transdisciplinary fields to address socio-biophysical predicaments.

As explained in detail in two seminal articles on the history of the field, ecological economics (EE) emerged in response to concerns over worsening pollution, population growth, resource scarcity, inequality, and systems models predicting dire consequences if these concerns were not addressed [12,13]. Ecological economists recognize that all economic production uses energy to transform raw materials extracted from nature into economic products and waste, degrading the ecosystem's essential life support functions. The physical scale of the economy is limited by finite resources of useful energy and matter that must be shared with other species. Economic goals are unavoidably normative and should include the just and equitable distribution of both finite resources and power. Given scarce resources and unmet needs, society should strive to achieve the greatest welfare obtainable from finite stocks and flows of low-entropy matter-energy, without threatening the welfare of future generations. These goals are often summarized as sustainable scale, just distribution, and efficient allocation. The breadth and depth of the field requires a transdisciplinary lens, integrating theories, tools, methods, and values from the natural sciences, social sciences, and humanities [14-22].

Ecological economics was formally established as an academic discipline with a journal and International Society in 1989, and one of the fields' founders, Robert Costanza, laid out a research agenda in 1991 [23]. Why does this Special Issue attempt to again 
lay out a research agenda nearly 30 years later? For two reasons. First, since the field was formally established in 1989, all the problems the field was founded to address have grown considerably worse. Over half of all industrial $\mathrm{CO}_{2}$ pollution has been emitted since then, accounting for nearly half the anthropogenic increase in atmospheric $\mathrm{CO}_{2}$ [24]. Annual emissions have increased by two-thirds, and 2019's emissions broke all previous records [25]. Species extinction rates exceed background rate by about three orders of magnitude and occur both across geographies and taxonomic groups [26,27]. Inequality in wealth, income, and power has sky-rocketed in most countries [28]. The list could be extended ad nauseam. While it is impossible to know what would have happened if the field of ecological economics did not exist, we clearly have not achieved the goals we set for ourselves. Second, the field has evolved considerably since it was founded, with different factions moving in different directions. There is a growing debate over the future of the field. A new research agenda can help identify what paths will best help us achieve our goals.

It is only appropriate that the research agenda for ecological economics be primarily defined by the young ecological economists who will be implementing it. This Special Issue presents the research agendas of mostly young ecological economists together with a few leaders in the field. Most participated in the Economics for the Anthropocene (E4A) or Leadership for the Ecozoic (L4E) collaborations between University of Vermont, McGill University, and York University (E4A only), at the Canadian Society for Ecological Economics 2018 Student Symposium, which brought together 28 Ph.D. students and postdoctoral researchers to share their in-progress research and discuss the future of ecological economics (EE). A dominant theme in most of the articles is the need for greater attention on social and cultural issues, which tend to be under-represented in the literature despite their centrality to the EE framework [29]. We must acknowledge that the articles in this issue under-represent views from the Global South and many excellent ecological economics programs worldwide, and we encourage more efforts to define the future of our field.

The remainder of this paper briefly describes changes in the field of ecological economics over the past 40 years and the emergence of different schools of thought. Reflecting the contributing authors' views to the research agenda, we pay close attention to the social sphere, community, and culture and their call for a new research agenda for ecological economics steeped in radical social research. We will then briefly describe the various contributions to the issue in the context of some of the ideas we layout.

\section{Evolving Schools of Thought within EE}

The 1970s was a foundational time for environmental scholars. The Limits to Growth report [30] provided the most notably empirical data demonstrating humanity could no longer work within the business-as-usual paradigm. At the same time, Nicholas Georgescu-Roegen, mentor to Herman Daly, provided a conceptual framework for ecological economics based on material and energy flows of production and consumption [14]. Georgescu-Reogen's The Entropy Law and the Economic Process and Frederick Soddy's Wealth, Virtual Wealth and Debt [31] laid the foundation for ecological economic thinking. Ecological economics began as a joint effort by natural and social scientists to address major shortcomings in both of its patronymic fields to understand and manage ecological and social challenges. Traditional ecology focused primarily on natural systems unaffected by humans, which made no sense in the modern world. Mainstream economics assumed production was a function of labor and capital only, largely ignoring raw material and energy inputs and waste outputs, and pursued the impossible goal of endless exponential growth on a finite planet with little regard for just distribution [9,32]. Initially, any economist interested in environmental issues or ecologist aware that humans were an integral part of the global ecosystem was considered a natural ally, but schisms quickly appeared, particularly among economists. Herman Daly found the contributions of mainstream economists to be at best inadequate and at worst actively harmful. He resigned from the board of the Beijer 
Institute for Ecological Economics on the grounds that the other leading economists in the group were too neoclassical. During the early 1990s, the field began to attract a variety of socio-economists, who viewed the economy as a co-evolutionary system embedded in and inseparable from other social institutions, including politics. Power and privilege, reflected in market institutions, shape both institutions and culture, including theories about human behavior, which in turn shape human behaviors and values [9,13,32]. Daly shared many of these views, explicitly viewing people as "persons in community", not isolated individuals, and adopted Polanyi's perspective that "in a capitalist society instead of economy being embedded in social relations, social relations are embedded in the economic system", noting that "it is this reversal that an economics for community cannot tolerate" [33].

Among ecologists, a growing awareness of transdisciplinary research's importance led to the development of numerous transdisciplinary societies and journals, providing alternatives to ecological economics. Mainstream economics, in contrast, remained highly disciplinary, while the impact factor of the journal Ecological Economics rose steadily, attracting mainstream economists with transdisciplinary interests to the journal and hence to the field. At the same time, ecologists striving to have a greater impact on policy decisions recognized that economics is the most influential of the natural sciences and the most reliant on the quantitative mathematical tools familiar to natural scientists. They began allying with mainstream economists and applying mainstream economic tools, especially monetary valuation of ecosystem services, to ecological problems [12]. The circular economy also became tightly linked with ecological economic research; while some praise it for its role in improved recyclability and reusability, there is general criticism that it does not contribute sufficiently to fundamental behavior change and that the goal of zero waste is inherently unattainable in line with the rules of entropy [34-36].

Spash $[17,37]$ identifies three schools of thought resulting from these trends that now dominate the field: (1) mainstream new resource economists based on equilibrium models, marginal analysis, and internalizing ecological costs into economic decisions; (2) new environmental pragmatists, willing to adopt whatever theories, tools, and methods are likely to have the most immediate impacts on environmental problems; and (3) radical social ecological economists who focus on alternatives to capitalism and recommend transformative social measures. Spash argues that those doing anything but the third category, radical social ecological economics, are not actually adhering to ecological economics's founding principles [14].

Spash rejects what he calls new resource economics and new environmental pragmatists on the basis that ecological economics developed partially as a critique of environmental economics, and it is, therefore, inappropriate for ecological economic scholars to use orthodox economic tools for problem-solving $[14,38]$. Echoing many ecological economists, Spash argues that, "the prevalence of the tools and methods of resource and environmental economics within ecological economics is not something to celebrate. Indeed, from a heterodox economic perspective, this is just another case of territorial annexation by the mainstream. This is just how the political battles within economics operate and how, until now, the non-conformist minority of blasphemous economists has been overridden by the conformist majority". This particular argument has characterized Spash's work for years $[14,39]$.

While Spash suggests there is no overlap between socio-ecological and new resource economics [38], implying a rejection of any use of prices or other market mechanisms, another strand of ecological economics perhaps most associated with Daly and his followers (including us) believes this is too extreme. This strand shares Spash's aversion to neoclassical economics (NCE) and indeed many of his views on socio-ecological economics, but also acknowledges that "policies must recognize that we always start from historically given initial conditions" [17], including the modern market economy (which is emphatically not the economy described by neoclassical economic theory). This does not imply one should not try to change the system radically, but rather that evolutionary systems generally evolve new structures from old. Armchair theorizing of radical economic 
transitions can never predict actual outcomes in complex, evolutionary systems. However, the apparent impossibility of endless economic growth and undesirability of worsening distributions of power, wealth, and income demand action. Markets are ill-suited for achieving ecological sustainability, social justice, or allocating information and other essential, non-rival, or non-excludable resources $[39,40]$. While prices cannot tell us where to set ecological and ethical goalposts, once scientific and moral principles set them, prices can be one of many useful leverage points for reaching them [41]. Within a just and sustainable system, markets also help individuals to satisfy their tastes [42]. From this perspective, tools are tools-what matters is the goals those tools are used to achieve, their effectiveness at achieving them, and the moral vision that guides their use.

Daly and Spash both reject the idea that markets alone could generate a sustainable, efficient, welfare-maximizing equilibrium if only we could internalize ecological costs into market prices, which is a central axiom of environmental economics. While the goal of sustainability is laudable, it is impossible to reduce the myriad values of nature to a single number, or for a single feedback signal to drive the complex ecological-economic system to an equilibrium. In complex systems, innumerable feedback loops are required to maintain any dynamic homeostasis, changes are often abrupt and non-linear, and marginal analysis is inappropriate near any threshold. Behavior of complex systems is an integral part of ecological economics, suggesting the need for more research on the overlap between complexity economics and ecological economics. Complexity economics uses similar approaches as those utilized within ecological economics, with a significant deviation in its criticism of a steady state [43], which is also its central differentiation from mainstream neoclassical economics [44]. The complexity economics framework sees the economy as in a state of constant change. More work could be done to bring these two heterodox disciplines together.

We are currently reaching or exceeding many ecological and perhaps social thresholds simultaneously. Pareto efficiency is irrelevant in a fossil-fueled economy in which resource extraction and waste emissions inherent to all economic production unavoidably make others worse off. Monetary valuation of ecosystem services weights preferences by purchasing power, which means it is guided by the moral vision that richer people deserve more say in the allocation of our shared inheritance than the poor, and hence is incompatible with the just distribution of wealth and power.

For environmental pragmatists, "the most important role for research is to be pragmatic and employ whatever approaches are effective to inform the policy community about environmental problems and their solution" [45]. This does not mean they do not desire radical changes towards a more just and sustainable society, only that they recognize such changes take time, while environmental problems are urgent. We have some sympathy for this approach and recognize the serious concern that the tools we use to analyze or solve a given problem are shaped by our worldviews and shape them [46]. A focus on the monetary values of nature may reinforce the idea that nature only has instrumental values for which we can develop substitutes as effectively as one dollar can substitute for another. In contrast, extrinsic monetary incentives and framing problems in terms of markets and money may promote self-interested behavior and crowd out intrinsic incentives to promote the common good [47-50]. Solving our most pressing socio-ecological problems will require cooperation and collective action [40,51]. Whether monetary valuation and market mechanisms help or hinder progress towards EE goals is an empirical question, albeit difficult to test.

Many ecological economists blame the infiltration of inappropriate mainstream economic approaches into ecological economics on the methodological pluralism that has characterized the field from the start and is perhaps most as associated with Norgaard and Costanza's work. Methodological pluralism asserts that ecological economics requires theories, tools, and methods from many disciplines to understand and solve ecological economic problems. 
In Costanza's words, in studying the relationships between ecosystems and economic systems a large measure of "conceptual pluralism" is warranted. There is probably not one right approach or paradigm, because, like the blind men and the elephant, the subject is too big and complex to touch it all with one limited set of conceptual tools. The Journal will therefore pursue a strategy of pluralism [32].

Norgaard makes similar points [52]. Both stress that the ecological economy is coevolving with human society and the rest of nature. It is impossible to consistently and accurately predict the future of any evolutionary system, and hence to predict what methods and tools might be required to understand the system in the future-pluralism acknowledges the uncertainty of knowledge and avoids hubris. However, this does not mean that all methods and tools are appropriate. Goddard et al. [53] argue that neoclassical economics is based on doxa (beliefs) rather than episteme (science), and hence lies outside their call for methodological pluralism. It follows then that the use of NCE theories and analysis can reinforce this doxa, which could indeed undermine the EE paradigm and goals. We strongly support intelligent methodological pluralism that excludes unscientific approaches or those incompatible with the EE paradigm and goals, but share the concern of many ecological economists about the growing influence of NCE in EE.

In his paper "The second generation of ecological economics: How far has the apple fallen from the tree?", Plumecocq [54] processed 6237 abstracts published in 4 journals from 1989 to 2014 to examine how ecological economic discourse has evolved. Plumecocq found that from 1989 to 1999, the focus of discourse was on conceptualizing ecological economics and situating itself against neoclassical economics. From 2000 to 2002, scholars began applying mainstream economic concepts to the newly established framework. In 2003-2005, the discourse shifted to a focus on biodiversity issues, followed by a phase of methodological development in 2006-2007. Beginning in 2008, the functionalist approaches begin to appear starting with an increase in research on "willingness to pay" in joint use with biophysical indicators such as the ecological footprint. While the concept of resilience emerged in 2013, the discourse was dominated mainly by ecosystem service analysis. Plumecocq begins his discussion saying, "Results drawn from textual analysis seem to indicate (i) a tendency of EE to move closer to the discourse produced in the field of environmental economics, and (ii) the co-emergence of the notion of ecosystem services on the one hand, and the resort to monetary valuation techniques on the other hand". In short, what Spash identifies as new resource economics and environmental pragmatism dominates the literature in the field.

Although a basic premise of ecological economics is that the economy is a subsystem of the environment and society, society and culture do not make up a significant portion of published material within ecological economic literature. The Wordle in Figure 1 shows the most commonly used words in the Journal of Ecological Economics (EE) from 1989 to 2015, created by Arruda and Dolter [55]. There is a conspicuous dearth of keywords referencing inequality, power relations, the underlying cultural dimensions driving our ecological emergency; visions for a just and sustainable society; or the need for radical transformative change, despite a recent survey finding that $72 \%$ of ecological economists believe such radical change is necessary [56]. Many ecological economists conclude in dismay that the field is well on its way to converging with environmental economics [17,57-59]. 


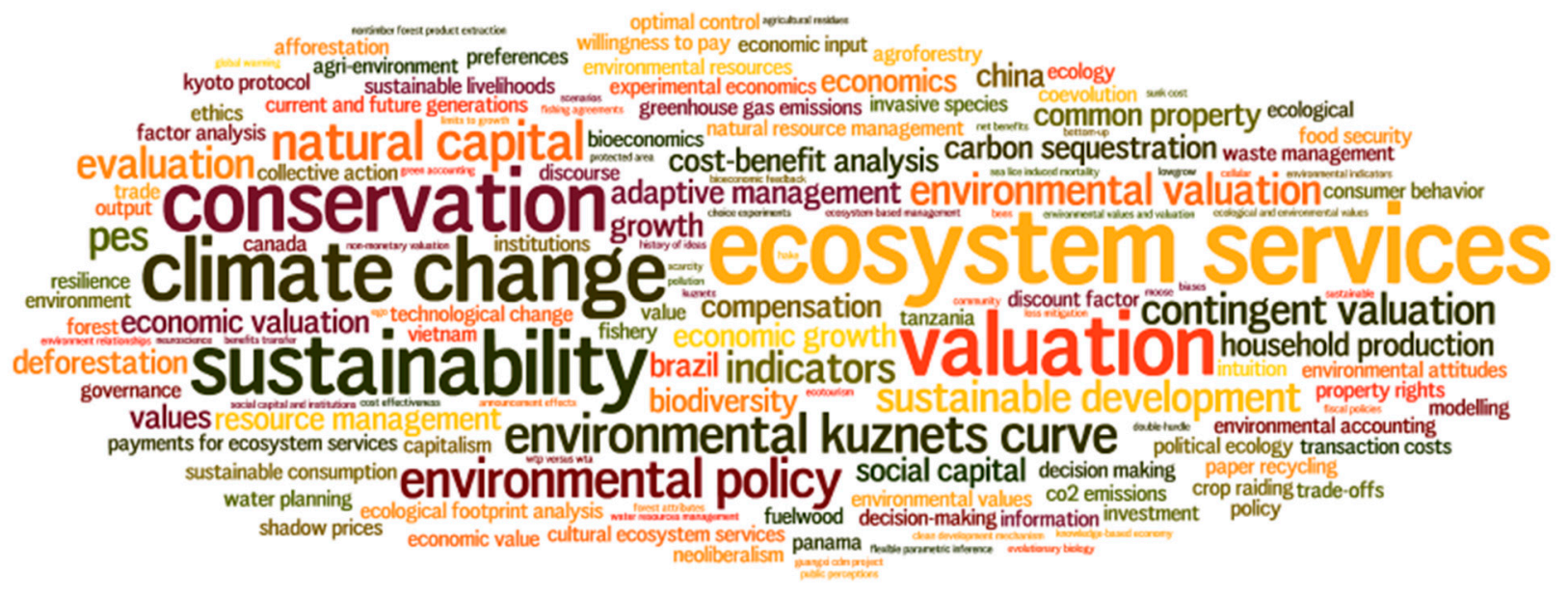

Figure 1. Wordle of themes in the Journal for Ecological Economics from Arruda and Dolter (2016).

Research on our economy's biophysical foundations is essential, but also not useful if we cannot turn knowledge into action, which requires a deep understanding of the social sphere. Furthermore, we cannot call for limits on extraction and pollution without discussing the underlying power structures that generate our current outcomes and determine winners and losers from such limits. The approaches of mainstream economics make rigid assumptions about human behavior and human society that contradict empirical evidence, with evidence that disseminating these views and policies based on them may shape human behavior in ways ill-suited to solving collective action problems [47,48,60-64]. The contributions to this Special Issue acknowledge that achieving a just and sustainable society requires research directed towards understanding and shaping culture, society, values, and behavior. Collective action requires cooperation, which in turn requires social relationships that promote mutual flourishing between members of society and between societies, which in turn requires a deeper understanding of unequal power relationships and the economic institutions that give rise to them. In short, ecological economists should pay more attention to the social sphere.

\section{The Neglected Social Sphere}

Ecological economics is a transdiscipline, spanning knowledge from physics and ecology through the social sciences and ethics. No individual can master all these fields, and it makes sense for researchers to concentrate on what they know best. In general, the natural sciences are better understood than the social sciences, which are inherently far more complex and challenging. Furthermore, scientists often seek to better understand complex systems by focusing on constituent parts. Nevertheless, ecological economics is ultimately focused on synthesizing insights from the natural and social sciences to build a more just and sustainable society, a task seriously complicated because society is undergoing rapid evolution. In just the past 10,000 years, society has evolved from small bands of around 200 hunter-gatherers in which everyone knew each other to our current situation of nearly 200 deeply interconnected nations with populations ranging from $\approx 11,000$ to 1.4 billion. Societies change profoundly as their scale and connectivity increases, with the emergence of inherently unpredictable new properties [65-70]. Within the social sciences, there is a proliferation of theories about how societies function and normative concepts of a good society. It is far easier to define what is biophysically possible (or impossible) than what is socially desirable, but ecological economics must ultimately balance the two. We cannot change physical or ecological laws, but we can help steer society's evolution. We argue that this is, in fact, what most social scientists implicitly try to achieve. Ecological economics is explicitly dedicated to improving quality of life rather than quantity of consumption [71-73], but achieving this goal requires attention to the social sphere. The contributors to this Special Issue worry that the social sphere has received too little attention in ecological economics, and a research agenda for the field 
must reflect this. We cannot let the difficulty of social sciences and values deter us from giving the social sphere the attention it deserves.

In what follows, we discuss both society and culture, and it behooves us to explicitly define these terms. No definition is without controversy, but for culture we use here one proposed by Henrich [74], "the large body of practices, techniques, heuristics, tools, motivations, values, and beliefs that we all acquire while growing up, mostly by learning from other people". A society is a group of people bound together by a common culture. A single individual can identify with multiple cultures and societies at different scales-for example, a Canadian, an academic, a maker, or a progressive.

Understanding the role of the social sphere in the research agendas proposed here helps to examine how the current research agendas in EE approach it. Beginning at one extreme, some biophysical economists largely ignore the social sphere. Ecological economics unquestionably requires a deep understanding of ecological and physical processes, and ecological economists trained in natural sciences have a comparative advantage in research in these areas. This research is vital, but biophysical scientists have already made significant progress. Our failure to address biophysical crises such as climate change stems not from our lack of understanding of biophysical systems but rather from an inadequate understanding of how to convince society to react to this knowledge.

Some ecological economists apply mainstream tools that adopt a narrow vision of the social sphere. The modern market economy began emerging in the 18th century as traditional economic relations of reciprocity, redistribution, and social obligations were, with the aid of the modern state, dismantled and replaced by formal market institutions in which labor and nature were merely factors of production to be traded as commodities, separate from other social relations. This transition both required and drove changes in human behavior towards rationality and self-interest [33]. Mainstream economics views such institutions and behaviors as both desirable and immutable. Individual goals of utility maximization scale up to the societal goal of maximizing economic surplus, conventionally defined in monetary values. System behavior is reduced to a mathematical equilibrium framework, with optimal results emerging inexorably from initial premises, in an approach ill-suited for analyzing qualitative change or continually evolving social systems [75]. Optimization requires reducing cultural meaning to a monetary or numeric value, ignoring the role of complex social dynamics. The mainstream adoption of methodological individualism, closely associated with rational choice theory, assumes that all social phenomena are explained by individual motivations and preferences [76]. Culture and society should only be changed if it promotes conformance to the market economy.

An example of the mainstream approach is efforts to estimate and sum individual's willingness to pay for ecosystem services then internalize these values into market prices [77], on the assumption that "society should make changes in environmental resource allocation only if the results are worth more in terms of individuals' welfare than what is given up by diverting resources and inputs from other uses" [78]. Social values are simply the summation of individual values, which are exogenous, not shaped by the economic system or society. This focus on the individual is a progressive liberal habit of mind that implicitly maintains the system that upholds the sovereignty of the individual despite the fact that collective choice and collective action are necessary to address climate stability, biodiversity, global pandemics, and many other ecological economic problems $[79,80]$. Addressing these problems may require seeing the individual as a single part of a cohesive unit, not as an individual unit for analysis [81], more in line with Daly's original argument that the most important factor for wellbeing is a communitarian way of living.

However, not all efforts at monetary valuation seek to commodify nature. Costanza et al. [82] for example explicitly reject the argument that internalizing externalities will lead to some sort of social optimum, but also argue that ignoring the values of nature leads to the worst outcomes. Their analysis includes cultural ecosystem services, defined as the "aesthetic, artistic, educational, spiritual, and/or scientific values of ecosystems" [82], an approach expanded on by the Millennium Ecosystem Assessment to include "the nonmaterial 
benefits people obtain from ecosystems through spiritual enrichment, cognitive development, reflection, recreation, and aesthetic experience" [82], thus recognizing different cultures may have different values, not all of which can be expressed in monetary terms.

Social-ecological economists generally recognize that different societies and cultures have different values for nature, from instrumental to spiritual, expressed in different languages. Environmental conflicts often stem from conflicts over values [83]. Decisions based on monetary values alone prioritize a narrow Western definition of market value. Some socio-ecological economists reject even the terms natural capital and ecosystem services as an effort to commodify nature (we reiterate, however, that the phrase "ecosystem services" implies commodification no more than the phrase "public services").

Another common tool in ecological economics offering flexibility with respect to the social sphere is system modeling. This represents a vast improvement over mainstream economic models and arises from ecological economics' theoretical history in systems sciences and hard system dynamics. While systems models can be quite complex, they nonetheless must simplify the system to understand individual components better. Attempts to include all variables would be as useless as a 1:1 scale map of the world, and the difficulty of including social variables means they are often neglected. Such models can provide important insights to inform broader social and cultural analyses but can also internalize mainstream economic views on the role and goals of society and contribute little to understanding the social sphere.

Many ecological economists seek to replace GDP with more socially attuned economic indicators that account for inequality, social ills, the household economy of reproduction and caring, and other non-monetary aspects of social wellbeing [84]. These efforts have influenced mainstream economists and even politicians. Nicolas Sarkozy, the former French president, argued that reliance on GDP as the primary statistic for policy creation contributed to the 2008 financial crisis. In the crisis' aftermath, he commissioned a report on GPD and its alternatives, led by Nobel Laureates Joseph Stiglitz and Amartya Sen. Their report starts, "There is no single indicator that can capture something as complex as our society. But because what we choose to measure and how we construct our measures can have such an important role in the decisions that are made, it is important that there be an open and public discussion of our systems of metrics" [85]. They are alluding to what Jeroen van den Bergh refers to as the "GDP paradox: the fact that it's widely proven and accepted that Gross Domestic Product ... is not a good indicator of progress, and yet society is unable to let it go" [86]. Van den Bergh's alternative is what he calls "agrowth", the aim of which is "to let go of economic growth as a sufficient and even necessary condition for realizing welfare, and instead take a rational approach to public decision-making ... As a society, we need to realize that growth fetishism is a constraint on our search for human progress" [86]. While Van den Bergh's overarching assessment of GDP is on point, his agrowth parameters prioritize individual wellbeing [87].

Other approaches within the current research agenda put culture and society at the center of their analysis. Quilley, for example, believes that societal collapse is likely, and that the new society must emerge on the basis of reorganizing the released resources into an entirely new system based on a gifting and livelihood economy-which is an economy engrained in family and kin relationships, greater dependence on the community, and is rooted in place-bound networks. This deemphasizes personal identity and in favor of community wellbeing [88-92]. Channeling Naess [93], Spash favors a more philosophical and culture-oriented "deep ecological economics" that emphasizes ethical conduct and environmental values as primary indicators and motivators for economic wellbeing. His primary concern is about human alienation and domination over nature and how this is built into a patriarchal capitalist society. Ecological economics should be explicitly normative; integrate social, ecological, and economic discourse; and explicitly seek to forge a more socially just and ecologically sustainable political economy [38].

We believe that fully integrating the social sphere into ecological economics requires an evolutionary approach that recognizes cultures and societies as evolving systems that 
shape human behavior, ethics, and environmental impacts. Forging an alternative political economy capable of addressing our current social and ecological challenges requires intentional change of our culture, specifically our worldviews, institutions, and technologies.

A major evolutionary transition occurs when individuals that could previously replicate independently come to cooperate to such a degree that they merge into a larger organism. For example, previously independent archaea and bacteria merged to form eukaryotic cells, from which all complex life has evolved. Previously independent eukaryotic cells merged to become multi-cellular organisms whose individual cells are no longer capable of solitary survival [53]. Humans and a handful of other social organisms have merged to become what are essentially superorganisms. Humans not only cannot survive apart from their group, but their groups cannot survive without inherited, often place-specific cultural knowledge that took generations to accumulate and cannot be mastered by a single individual, no matter how intelligent $[67,74]$.

Among humans and a few other evolutionary lineages (e.g., social ants, bees, naked mole rats, etc.), natural selection acts more strongly on the group than the individual. And while this may be the exception, rather than the rule, these groups consisting of more cooperative individuals have greater fitness than groups with selfish individuals, even as selfish individuals outcompete cooperative ones within the group. Selfish individuals who prioritize their own fitness over that of the group are akin to cancerous cells that prioritize their own reproduction over the organism. Species have pursued various paths to achieving superorganism status, with numerous similarities, driven primarily by genetic evolution. However, it is important to remember that natural selection requires only reproduction, heritability, and variation, and genes are only one mechanism of inheritance. Variation between cultures often exceeds variation between individuals within a culture, in which case culture is the dominant unit of selection and must be the unit of analysis. Culture shapes our preferences, our values, and our economic systems $[69,94,95]$. Methodological individualism is absurd, as is the emphasis on competitive self-interest. Dobszhansky once stated that nothing in biology could be understood except through the lens of evolution [96]. Economic systems vary widely across cultures, and hence are part of culture. Humans evolved the genetic capacity to develop cultures, and thus cultures are inherently biological. Nothing in economics can be understood except in the light of cultural evolution.

The left has historically been hostile to evolutionary perspectives, which they claim justify the status quo, including power differentials, sexism, myopia, destructive ecological behavior, and so on, as natural and hence either pre-determined or outside the realm of morality [97]. Nothing could be further from the truth. While genetics influences our behavior, culture profoundly shapes our attitudes towards our deepest biological needs, such as sex, food, and even self-preservation (think soldiers going to war). Cultural evolution is so powerful it drives genetic evolution-mastery of fire led to the evolution of a smaller stomach and shorter intestines, the ability to carry water enabled the evolution of endurance running and sweating, domestication of cattle led to lactose tolerance [74]. Even morality evolved to increase fitness. Virtually all cultures define a good person as someone who puts the group ahead of the individual and the evil person as one who puts the individual ahead of the group [94]. Early in our evolutionary history, when individuals tried to amass more than their share of resources and power, they would be socially condemned, ostracized, or even killed [98]. The result of this was the self-domestication of humans. Just as dogs are a domesticated, juvenilized, less aggressive form of the wolf, modern humans may be a domesticated, juvenilized, less aggressive form of early hominids [99].

Humanity's planetary success was driven by our ability to form cooperative groups bound together by shared social myths (e.g., nationality, religion, tribalism) and institutions that punish selfish behavior [74,100]. Today, the most serious challenges currently faced by society are predominantly prisoner's dilemmas, which can only be solved through cooperation at the appropriate scale. Nationalism, racism, and partisanism threaten intergroup cooperation, as do squabbles that continually subdivide academic fields focused on sustainability and justice. 


\section{Devising a Research Agenda Inclusive of the Social and Cultural Sphere}

The young EE scholars in this Special Issue bring a diversity of perspectives. Their work remains true to the central focus of ecological economics on social justice and economic downscaling while calling for a greater emphasis on culture and society. They acknowledge that intellectual pluralism entails tensions and disagreement but strive to both embrace and transcend difference by acknowledging our shared normative foundations and our shared project: socio-ecological transformation toward justice and sustainability and the radical change this entails.

Our view is that radical change is not only unavoidable but also already underway. In complex systems, increasing critical parameters beyond a critical threshold can flip a system into a radically different alternative state from which it can be extremely difficult to return $[101,102]$. The planetary boundaries literature warns that we have already crossed several such ecological thresholds [103]. Rapidly rising inequality, debt, financial speculation, outsourcing, and automation are only a few of the critical economic parameters that could quickly exceed critical thresholds. It will take radical changes to the global political economy to restore these critical parameters to safer levels if it is not too late to do so already $[104,105]$. Compared to business as usual—among the riskiest and most radical options on the table- -the authors' radical changes in this Special Issue may be fundamentally conservative.

Like all the articles in this Special Issue, Ruder and Sanniti [106] recognize that achieving a just and sustainable socioeconomic system will require radical transformative change. Utilizing the gendered analysis of ecofeminism, they argue that one of the main drivers of our current predicament is a hierarchical, dualistic Western worldview in which reality is divided into distinct parts with one superior to and dominant over the other: humans over nature, mind over body, men over women, rationality over emotion, and of the powerful over the weak. This ontology is predatory because it perpetuates dominance and exploitation, both of nature and of the less powerful. They favor instead a worldview that acknowledges and fosters "interconnection, dependence, and kinship in relations between humans, humans and nonhuman life, and humans and nature". While they praise ecological economics for acknowledging the biophysical limits of economic growth and its efforts to achieve ecological sustainability, they claim the field neglects fundamental power differentials and continues to perpetuate the dualistic ontology they decry. They lament a growing emphasis in ecological economics on "hard" quantitative models and empirical research at the expense of normative philosophical and qualitative analysis. They argue that a research agenda in ecological economics must focus on overcoming predatory ontologies, implementing transformations, and analyzing power and moral imperatives.

Pirgmaier and Steinberger take a similar stance to Ruder and Sanniti in arguing that ecological economics has some strengths, but nonetheless requires radical changes to its research agenda if it hopes to stimulate the radical transitions required for a just and sustainable future. Specifically, they call for systemic approaches that prioritize the role of power, class, geographical and historical perspectives, and human wellbeing. The proliferation of mainstream economic frameworks undermines the field's progress. Their article focuses primarily on changing institutions, but also on changing worldviews, especially concerning what constitutes human flourishing, the goal of economic activity. A focus on human flourishing requires we interrogate the "purpose and outcomes of consumption", to which we would add that meaningful work-production-is also essential to human flourishing. They favor an explicitly Marxist approach with a focus on how capitalism drives ecological and social exploitation. Defined as an upwards "spiraling, not circular, system of exchange" that concentrates surplus in the hands of the few, capitalism is clearly incompatible with a sustainable or just economy. They also stress that it is impossible to separate theory from action when theories profoundly impact society's trajectory. Research agendas can transform not only academic fields, but also society.

However, such transformation is limited and blocked by systems that benefit from them. Kish shows how advances in advertising theory in tandem with the wide-spread 
use of social advertising platforms, such as Facebook, have significantly increased corporations' ability to convince people to buy. These tech companies activate historically effective psychological tactics, mainly convincing individuals that they need something to solidify their identity, alongside enormous amounts of user data to meet the needs of their customers with ever increasing efficiency. The customers of these social advertising platforms are not the user, but the corporations paying to get the most possible space on user screens. The user's attention is the commodity. Kish refers to this as the commodification of attention and argues that it is one of the most effective barriers to deep socio-ecological change. Companies take advantage of historical neuroticisms to perpetuate conspicuous consumption. They also intentionally contribute to fractured information ecologies [107] to obscure truth around sound science, such as climate change, to increase profits. This co-evolution between advertising tactics and advancements in technology has dramatically improved corporations' ability to target and sell to individuals. In the face of a lack of coherent community values, people turn to conspicuous consumption to create self-identity, which they portray on these social media platforms to garner self-esteem. Kish argues that part of the problem is the lack of clear and associative values across ecological economics work.

Wironen, Bartlett, and Erickson tackle this difficult challenge in ecological economics: how to collectively define normative values. While grounded in science, EE pursues explicitly normative goals requiring a radical socio-ecological transformation driven by collective action. If this process is to be democratic, it will require broad consensus on the legitimacy of the field's normative values, which are distinctly different from the implicit normative and individualistic values that guide both conventional economic theory and capitalist economics in practice. While other ecological economists have used deliberative discourse to address specific problems in ecological economics, the authors argue that a process of democratic deliberation can play a critical role guiding a major socioecological transition in at least three ways. First, engaging individuals in a deliberative discourse shifts their focus from individual consumer to citizen and member of society. Second, in contrast to voting, which simply aggregates individual preferences, deliberation and public reasoning actively shape preferences, and hence the resulting social choices. Finally, and perhaps most importantly, deliberation in the public sphere can legitimate the normative values that guide and shape our society, although whether deliberation leads to the legitimation of the normative values of ecological economics is an open question. The article acknowledges several open questions about democratic deliberation, one of which we believe is particularly important. The "open forums" in which most deliberation currently occurs are on social media in which participants self-select their own forums, leading to polarization. What is left unmentioned is that proprietary algorithms designed solely to maximize ad revenue determine the discourse to which participants are exposed, systematically presenting increasingly extreme views.

Although stating in different terms than the legitimization of EEs normative goals, Quilley and Zywert also recognize that "any real paradigmatic, peaceable transformation toward a sustainable society would require bringing a critical mass of the population in high-income countries on board". In their view, this means developing approaches to political economy that unite both the right and the left, both motorheads and greens. One approach to achieving this is for ecological economics to focus on livelihood-"the household, the informal/DIY economy, and the culture and rituals of reciprocation" - as a complement to the state and market. Prior to the modern era, the survival unit for most people consisted of family and community, to which individuals had deep moral obligations that in effect suppressed their individuality and mobility. Economic relations were inseparable from social relations, and frequently based on reciprocity, gifting, and shared use of resources held in common, with access regulated by social norms. As chronicled by Polanyi, developing the modern economy required severing the connections between social obligations and economic activities. Currently, the right is typically portrayed as pro-market and anti-government, and the left vice versa. However, the market and state worked together to 
disembed the economy from society, transforming persons-in-community into individuals "with unprecedented degrees of spatial and social mobility", who could only survive by selling their labor on the market. However, markets are too unstable, profit-oriented, and exploitative to ensure survival, leading to a dual movement to protect society from market forces. This gave rise to the welfare state that worked in concert with markets to ensure its citizens' survival, replacing livelihood as the survival unit. The state and market resource are intensive, but so too the authors assert universal human rights and equality before the law, all driving and relying on continual economic growth.

Furthermore, disembedding individuals from their place-based communities favors over-exploitation of common property resources. The solution to this problem is to focus on the political economy of the survival unit and to restore livelihood as a third leg along with a diminished market and state, which means restoring the place-based community ties required for economics of reciprocity, gifting and common property managed by shared social norms, while also taking advantage of new technologies such as 3D printing that facilitate a do-it-yourself economy. Although we question the feasibility of such a system on a larger and broader scale, a greater emphasis on livelihood would reduce the ecological impacts of the state and market as survival units while appealing to large elements of the right and left, and hence could help achieve the critical mass of support required for a peaceful socio-economic transition. It would simultaneously undermine the individualism on which the modern political economy is predicated.

Roncancio et al. call for a transition from the Anthropocene, characterized by human domination of planetary processes, to the Ecozoic, characterized by mutually enhancing relationships across the community of life. While Quilley and Zywert call for greater focus on local community as the survival unit, Roncancio et al. focus on the community of life. The Anthropocene is based on humans' dualistic ontology as separate from and superior to nature; an epistemology of dominance of the rational, objective, Western scientific method and neglect of other ways of knowing or being; and an axiology prioritizing progress, growth, and improvement. They argue that educational institutions shape our cultures and help create the world we live in, then review textbooks in several social and natural sciences to show how higher education inculcates and perpetuates the ontology, epistemology, and axiology of the Anthropocene. To transition to the Ecozoic will require an ontology or worldview in which humans are part of an interconnected, mutually interdependent web of life; an epistemology of subject-subject relationships; and an axiology of relationality and reciprocity. Their agenda calls for more research on the ways in which our educational system perpetuates the Anthropocene and what alternative approaches will facilitate the transition to the Ecozoic.

The last two articles focus on specific but extremely important sectors of the economy. Bliss proposes a research agenda focused on non-market food systems, and by implication, non-market allocation of essential resources in general. He documents how market-based food systems are unjust, unsustainable, inefficient, and based on value monism. Market decisions are based on preferences weighted by purchasing power, favoring luxury consumption by the rich over the basic needs of the poor, with the result that they allocate resources to those who need them least. Purchasing power is rarely determined by productivity or contributions to society, and frequently by positive feedback loops in market economies in which wealth begets wealth. Agriculture is one of the greatest threats to global ecosystems in part because food producers pass their ecological costs on to society, and hence are ignored by market decisions. The price mechanism fails for food allocation because demand and short run supply are highly insensitive to price. Markets also reduce the cultural, spiritual, physiological, and ecological values of food to the single metric of price, suppressing value pluralism. Historically, the food economy was deeply embedded in social relations, but these connections were damaged by the great transition to the modern market economy. Bliss argues that the EE research agenda should explore ways to re-embed food systems into social relations, and that simply researching alternatives helps legitimize them, while calling attention to the problems of market allocation. 
Ament proposes a research agenda focused on money, which he shows "is a social relationship that forms the basis of human civilization". He argues that the dualistic worldview eloquently described by Ruder and Sanniti contributed to an atomistic and mechanistic economy theory in which money is primarily treated as a means to facilitate barter, with no other impact on social power dynamics. He explores the history of money and explains how it emerged from social dynamics of debt and credit. Our current system of private money creation by banks has profound implications for the distribution of wealth and power. It exacerbates economic instability and creates an unsustainable growth imperative. Ament concludes that money is a social relation and the basis of the modern economy. Our current monetary system is incompatible with the goals of ecological economics. Achieving those goals therefore requires the creation of alternative monetary systems, which much be guided by a clear understanding of the social relationships underlying money and hence the economy.

\section{Conclusions}

All the articles in the Special Issue call for changing culture and society. Culture is an evolutionary system $[67,74]$. While technology continually drives cultural and even genetic evolution (as discussed earlier), and many mainstream economists consider it the key solving our current problems, the articles here focus on the need to change both worldviews and institutions. In essence, they are calling for intentional cultural evolution [68] that must be informed by our cultural evolution to date. We conclude this editorial with some insights into how a cultural evolution lens could contribute to the research agendas proposed in this volume.

First, we would like to distinguish between proximate and ultimate causes. In this issue, several articles blame capitalism, colonialism, or some other -ism for both dualistic worldviews and the inequality and injustice that characterize the modern economy. We believe the truth is far more nuanced-capitalism and colonialism are proximate causes, but the ultimate cause is the evolution of humans as ultrasocial animals [108,109]. Ruder and Sanniti stress that othering is a "process of separation and estrangement of subject-object to permit domination". Many scholars call for a return to Indigenous worldviews that see humans as part of nature, which we believe is essential to a just transition, but few if any groups are entirely innocent of dualistic ontologies. Many tribal names for example translate as "the people", "the true people", or something similar [110], implying that other groups may not deserve the same moral consideration as the true people $[98,111]$. Group allegiance appears to be a defining characteristic of our species, and a group presupposes a non-group [67].

Human history has been characterized by the creation of ever-larger groups capable of coordinating their actions. One challenge we face is to achieve coordination on the scale of the problem. However, coordination can be achieved through cooperation based on mutual rewards or coercion of the weak by the strong. A second challenge is to promote voluntary cooperation. While we probably cannot avoid othering all together, we can strive to intentionally evolve cultural mechanisms that promote positive interactions with other groups based on mutual respect, fairness, and justice. Pre-agricultural cultures were far more egalitarian than modern society, and as we move towards a world in which the most important resources must be managed collectively for shared benefits, we may have much to learn from more egalitarian cultures.

An evolutionary perspective also raises questions about the role of rational analysis. Scientists are indoctrinated into a rationalist world view, in which objective science informs the public and decision makers, who then act appropriately [112]. However, natural selection acts on fitness, not rationality [113]. Belief in an omniscient and omnipotent God who inflicts eternal punishment on those who break his commandments may not be rational, but it can certainly promote pro-social behavior that increases a society's fitness relative to others [114]. Objective science itself suggests that human beliefs and behavior are affected less by appeals to reason than by appeals to emotion and social conformity [115]. 
As Wironen et al. note, in a group setting, it is difficult to espouse values that favor the individual at the cost to the group. In this context, deeply democratic deliberation can help shape norm and values that promote cooperation, altruism, and the group, and punish selfish behavior. The problem is that group cohesion is best created in opposition to other groups, and thus polarization is natural. The challenge is to coordinate activity across ever larger groups, or across groups of groups - the trend in human history that has allowed us to dominate the earth. Paradoxically, addressing the problems that human domination has caused may require the formation of even larger groups at the scale of the global challenges we currently face. We believe that for ecological economics to achieve its goals, we must learn how to change culture and society on an unprecedented scale.

In conclusion, we heartily support the call for new approaches to ecological economics since our old ones have thus far failed to achieve the world we all desire. We note, however, that the ecological economy is a complex and evolving system characterized by extreme uncertainty, profound ignorance, and accelerating rates of change. Social sciences seek to understand how human behavior drives social systems, but our theories affect the very behavior and culture they seek to understand [116]. The research agenda laid out here is explicitly intended to shape our society, but it is unlikely to do so in precisely the ways we predict, and it is hubris for any of us to believe otherwise. The ecological economics research agenda must therefore remain dynamic.

Author Contributions: Conceptualization, writing, and editing, K.K. and J.F. All authors have read and agreed to the published version of the manuscript.

Funding: This research was funded by Leadership for the Ecozoic and the Gund Institute.

Institutional Review Board Statement: Not applicable.

Informed Consent Statement: Not applicable.

Data Availability Statement: Not applicable.

Conflicts of Interest: The authors declare no conflict of interest.

\section{References}

1. Barr, C.; Zapponi, C. Who's Winning? Find out How Your Income Compares with Every Other Generation. Available online: http:/ / www.theguardian.com/world/ng-interactive/2016/mar/07/whos-winning-find-out-how-your-income-compareswith-every-other-generation (accessed on 5 May 2017).

2. Henderson, J.M. Millennials Earn Less Than Their Parents and the Recession Isn't to Blame. Available online: http:/ / www.forbes. com/sites/jmaureenhenderson/2013/11/30/millennials-earn-less-than-their-parents-and-the-recession-isnt-to-blame/ (accessed on 5 May 2017).

3. Malik, S.; Barr, C.; Oltermann, P. Young Single People Bear the Brunt of Generation Y's Economic Woes. The Guardian, 8 March 2016.

4. McGinnis Johnson, J.; Ng, E.S. Money Talks or Millennials Walk: The Effect of Compensation on Nonprofit Millennial Workers Sector-Switching Intentions. Rev. Public Pers. Adm. 2016, 36, 283-305. [CrossRef]

5. Ward, S.F. The Ultimate Time-Money Trade-Off. ABAJ 2007, 93, 24.

6. Worstall, T. Millennials Earn 20\% Less Than Boomers-Not as Important as You Might Think. Available online: http:/ /www. forbes.com/sites/timworstall/2017/01/14/millennials-earn-20-less-than-boomers-not-as-important-as-you-might-think/ (accessed on 5 May 2017).

7. Faber, M.; Proops, J.L.R. Evolution, Time, Production and the Environment, 2nd ed.; Springer: Berlin/Heidelberg, Germany, 1993; ISBN 978-3-540-58044-7.

8. Costanza, R. Visions of Alternative (Unpredictable) Futures and Their Use in Policy Analysis. Conserv. Ecol. 2000, 4. [CrossRef]

9. Costanza, R.; Alperovitz, G.; Herman, E.D.; Farley, J.; Carol, F.; Jackson, T.; Kubiszewski, I.; Schor, J.B.; Victor, P.A.; Colman, R. Building a Sustainable and Desirable Economy-in-Society-in-Nature; United Nations Division for Sustainable Development: New York, NY, USA, 2012.

10. Swimme, B. The Universe Story: From the Primordial Flaring Forth to the Ecozoic Era-A Celebration of the Unfol, Reprint edition; HarperOne: Oxford, UK, 1994; ISBN 978-0-06-250835-5.

11. Berry, T. The Great Work: Our Way into the Future, Reprint edition; Crown: New York, NY, USA, 2000; ISBN 978-0-609-80499-5.

12. Røpke, I. Trends in the Development of Ecological Economics from the Late 1980s to the Early 2000s. Ecol. Econ. 2005, 55, 262-290. [CrossRef]

13. Røpke, I. The Early History of Modern Ecological Economics. Ecol. Econ. 2004, 50, 293-314. [CrossRef] 
14. Georgescu-Roegen, N. The Entropy Law and the Economic Process; Harvard University Press: Cambridge, MA, USA, 1971; ISBN 978-0-674-25781-8.

15. Boulding, K.E. The Economics of Knowledge and the Knowledge of Economics. Am. Econ. Rev. 1966, 56, 1-13.

16. Daly, H.E. From Uneconomic Growth to a Steady-State Economy, Reprint edition; Edward Elgar Publishing: Cheltenham, UK; Northampton, UK, 2016; ISBN 978-1-78347-996-2.

17. Spash, C.L. New Foundations for Ecological Economics. Ecol. Econ. 2012, 77, 36-47. [CrossRef]

18. Alcott, B. Jevons' Paradox. Ecol. Econ. 2005, 54, 9-21. [CrossRef]

19. Ayres, R.U. Eco-Thermodynamics: Economics and the Second Law. Ecol. Econ. 1998, 26, 189-209. [CrossRef]

20. Schumacher, E.F. Small Is Beautiful: Economics as If People Mattered; Harper Perennial: New York, NY, USA, 1973.

21. Brown, P.G.; Timmerman, P. (Eds.) Ecological Economics for the Anthropocene: An Emerging Paradigm; Columbia University Press: New York, NY, USA, 2015; ISBN 978-0-231-17343-8.

22. Daly, H.E. Toward Some Operational Principles of Sustainable Development. Ecol. Econ. 1990, 2, 1-6. [CrossRef]

23. Costanza, R. Ecological Economics: A Research Agenda. Struct. Chang. Econ. Dyn. 1991, 2, 335-357. [CrossRef]

24. Frumhoff, P. Global Warming Fact: More Than Half of All Industrial $\mathrm{CO}_{2}$ Pollution Has Been Emitted Since. 1988. Available online: https:/ / blog.ucsusa.org/peter-frumhoff/global-warming-fact-co2-emissions-since-1988-764 (accessed on 30 November 2020).

25. Plumer, B. Carbon Dioxide Emissions Hit a Record in 2019, Even as Coal Fades. The New York Times. 3 December 2019. Available online: https: / / www.nytimes.com/2019/12/03/climate/carbon-dioxide-emissions.html (accessed on 1 February 2021).

26. Pimm, S.L.; Jenkins, C.N.; Abell, R.; Brooks, T.M.; Gittleman, J.L.; Joppa, L.N.; Raven, P.H.; Roberts, C.M.; Sexton, J.O. The Biodiversity of Species and Their Rates of Extinction, Distribution, and Protection. Science 2014, 344, 987-997. [CrossRef] [PubMed]

27. Sol, J. Economics in the Anthropocene: Species Extinction or Steady State Economics. Ecol. Econ. 2019, 165, 106392. [CrossRef]

28. Piketty, T. Capital in the Twenty-First Century; Harvard University Press: Cambridge, MA, USA, 2017; ISBN 978-0-674-97985-7.

29. Costanza, R.; Erickson, J.D.; Farley, J.; Kubiszewski, I. Sustainable Wellbeing Futures: A Research and Action Agenda for Ecological Economics; Edward Elgar Publishing: Cheltenham, UK, 2020; ISBN 978-1-78990-095-8.

30. Meadows, D.H.; Meadows, D.L.; Randers, J.; Behrens, W. The Limits to Growth. In Green Planet Blues: Critical Perspectives on Global Environmental Politics; Routledge: New York, NY, USA, 1972; Volume 102, p. 27. ISBN 0-451-05250-1.

31. Soddy, F. Wealth, Virtual Wealth and Debt; Noontide Press: Torrance, CA, USA, 1987; ISBN 978-0-317-53218-0.

32. Costanza, R. What Is Ecological Economics? Ecol. Econ. 1989, 1, 1-7. [CrossRef]

33. Polanyi, K. The Great Transformation: The Political and Economic Origins of Our Time; Beacon Press: Boston, MA, USA, 1944; ISBN 978-0-8070-5643-1.

34. Clube, R.K.M.; Tennant, M. The Circular Economy and Human Needs Satisfaction: Promising the Radical, Delivering the Familiar. Ecol. Econ. 2020, 177, 106772. [CrossRef]

35. Millar, N.; McLaughlin, E.; Börger, T. The Circular Economy: Swings and Roundabouts? Ecol. Econ. 2019, 158, 11-19. [CrossRef]

36. Korhonen, J.; Honkasalo, A.; Seppälä, J. Circular Economy: The Concept and Its Limitations. Ecol. Econ. 2018, 143, 37-46. [CrossRef]

37. Spash, C. The Need for and Meaning of Social Ecological Economics. Multilevel Gov. Dev. 2017, 2, 1-30.

38. Spash, C.L. The Shallow or the Deep Ecological Economics Movement? Ecol. Econ. 2013, 93, 351-362. [CrossRef]

39. Farley, J.; Schmitt, A.; Burke, M.; Farr, M. Extending Market Allocation to Ecosystem Services: Moral and Practical Implications on a Full and Unequal Planet. Ecol. Econ. 2015, 117, 244-252. [CrossRef]

40. Farley, J. Capitalism and the Steady State: Uneasy Bedfellows. In Positive Steps toward a Steady State Economy; CASSE NSW: Sydney, Australia, 2017; pp. 182-196.

41. Stiglitz, J.E.; Stern, N.; Duan, M.; Edenhofer, O.; Giraud, G.; Heal, G.M.; la Rovere, E.L.; Morris, A.; Moyer, E.; Pangestu, M.; et al. Report of the High-Level Commission on Carbon Prices; International Bank for Reconstruction and Development and International Development Association/The World Bank: Washington, DC, USA, 2017; pp. 1-61. [CrossRef]

42. Daly, H.E. (Ed.) Toward a Steady-State Economy; W.H.Freeman \& Co Ltd: San Francisco, CA, USA, 1973; ISBN 978-0-7167-0793-6.

43. Arthur, W.B. Complexity and the Economy; Oxford University Press: Oxford, UK, 2015; ISBN 978-0-19-933429-2.

44. Schasfoort, J. The Perspectives of Pluralist Economics. Complex. Econ. 18 September 2017. Available online: https://www. exploring-economics.org/en/orientation/complexity-economics/ (accessed on 1 February 2021).

45. Spash, C.L.; Ryan, A. Economic Schools of Thought on the Environment: Investigating Unity and Division. Camb. J. Econ. 2012, 36, 1091-1121. [CrossRef]

46. Bowles, S. Endogenous Preferences: The Cultural Consequences of Markets and Other Economic Institutions. J. Econ. Lit. 1998, $36,75-111$.

47. Bowles, S. Policies Designed for Self-Interested Citizens May Undermine "The Moral Sentiments": Evidence from Economic Experiments. Science 2008, 320, 1605-1609. [CrossRef] [PubMed]

48. Frey, B.S.; Jegen, R. Motivation Crowding Theory: A Survey of Empirical Evidence; CESifo Working Paper; CESifo: Munich, Germany, 2000.

49. Caruso, E.M.; Vohs, K.D.; Baxter, B.; Waytz, A. Mere Exposure to Money Increases Endorsement of Free-Market Systems and Social Inequality. J. Exp. Psychol. Gen. 2013, 142, 301-306. [CrossRef]

50. Kallis, G.; Gómez-Baggethun, E.; Zografos, C. To Value or Not to Value? That Is Not the Question. Ecol. Econ. 2013, 94, 97-105. [CrossRef] 
51. Farley, J.; Gowdy, J. Cultural Evolution, Multi-Level Selection and Institutions for Cooperation. In Sustainable Well-Being Futures: A Research and Action Agenda for Ecological Economics; Edward Elgar: Cheltenham, UK, 2020.

52. Norgaard, R.B. Environmental Economics: An Evolutionary Critique and a Plea for Pluralism. J. Environ. Econ. Manag. 1985, 12, 382-394. [CrossRef]

53. Goddard, J.J.; Kallis, G.; Norgaard, R.B. Keeping Multiple Antennae up: Coevolutionary Foundations for Methodological Pluralism. Ecol. Econ. 2019, 165, 106420. [CrossRef]

54. Plumecocq, G. The Second Generation of Ecological Economics: How Far Has the Apple Fallen from the Tree? Ecol. Econ. 2014, 107, 457-468. [CrossRef]

55. Arruda, J.; Dolter, B. Canadian Contributions to the Ecological Economics Jounral. 2016. Available online: https://cansee.ca/ (accessed on 1 February 2021).

56. Dube, B. Assessing ecological economics at 30: Results from a survey of ISEE members. In Sustainable Well-Being Futures; Edward Elgar: Cheltenham, UK, 2020; pp. 427-443.

57. Gowdy, J.; Erickson, J. Ecological Economics at a Crossroads. Ecol. Econ. 2005, 53, 17-20. [CrossRef]

58. Illge, L.; Schwarze, R. A Matter of Opinion-How Ecological and Neoclassical Environmental Economists and Think about Sustainability and Economics. Ecol. Econ. 2009, 68, 594-604. [CrossRef]

59. Pirgmaier, E. The Neoclassical Trojan Horse of Steady-State Economics. Ecol. Econ. 2017, 133, 52-61. [CrossRef]

60. Bowles, S.; Gintis, H. The Revenge of Homo Economicus: Contested Exchange and the Revival of Political Economy. J. Econ. Perspect. 1993, 7, 83-102. [CrossRef]

61. Marwell, G.; Ames, R.E. Economists Free Ride, Does Anyone Else?: Experiments on the Provision of Public Goods, IV. J. Public Econ. 1981, 15, 295-310. [CrossRef]

62. Frank, B.; Schulze, G.G. Does Economics Make Citizens Corrupt? J. Econ. Behav. Organ. 2000, 43, 101-113. [CrossRef]

63. Kirchgässner, G. (Why) Are Economists Different? Eur. J. Political Econ. 2005, 21, 543-562. [CrossRef]

64. Cipriani, G.P.; Lubian, D.; Zago, A. Natural Born Economists? J. Econ. Psychol. 2009, 30, 455-468. [CrossRef]

65. Henrich, J.; Boyd, R.; Bowles, S.; Camerer, C.; Fehr, E.; Gintis, H.; McElreath, R. In Search of Homo Economicus: Behavioral Experiments in 15 Small-Scale Societies. Am. Econ. Rev. 2001, 91, 73-78. [CrossRef]

66. Boyd, R.; Richerson, P.J.; Henrich, J. The Cultural Niche: Why Social Learning Is Essential for Human Adaptation. Proc. Natl. Acad. Sci. USA 2011, 108, 10918-10925. [CrossRef]

67. Moffett, M.W. The Human Swarm: How Our Societies Arise, Thrive, and Fall, 1st ed.; Basic Books: New York, NY, USA, 2019; ISBN 978-0-465-05568-5.

68. Wilson, D.S.; Hayes, S.C.; Biglan, A.; Embry, D.D. Evolving the Future: Toward a Science of Intentional Change. Behav. Brain Sci. 2014, 37, 395-416. [CrossRef]

69. Wilson, D.S. This View of Life: Completing the Darwinian Revolution, Illustrated edition; Pantheon: New York, NY, USA, 2019; ISBN 978-1-101-87020-4.

70. Christian, D. Maps of Time an Introduction to Big History; University of California Press: Berkeley, CA, USA, 2011; ISBN 978-0-520-24476-4.

71. Cattaneo, C.; D'Alisa, G.; Kallis, G.; Zografos, C. Degrowth Futures and Democracy. Futures 2012, 44, 515-523. [CrossRef]

72. D'Alisa, G.; Demaria, F.; Kallis, G. (Eds.) Degrowth: A Vocabulary for a New Era; Routledge: Abingdon, UK; New York, NY, USA, 2014; ISBN 978-1-138-00077-3.

73. Kallis, G.; Kerschner, C.; Martinez-Alier, J. The Economics of Degrowth. Ecol. Econ. 2012, 84, 172-180. [CrossRef]

74. Henrich, J. The Secret of Our Success: How Culture Is Driving Human Evolution, Domesticating Our Species, and Making Us Smarter; Princeton University Press: Princeton, NJ, USA, 2015; ISBN 978-0-691-16685-8.

75. Georgescu-Roegen, N. Methods in Economic Science. J. Econ. Issues 1979, 13, 317-328. [CrossRef]

76. Heath, J. Methodological Individualism. In The Stanford Encyclopedia of Philosophy; Zalta, E.N., Ed.; Metaphysics Research Lab, Stanford University: Stanford, CA, USA, 2020.

77. Bergh, V.D.J.C. Externality or Sustainability Economics? Ecol. Econ. 2010, 69, 2047-2052. [CrossRef]

78. Johansson-Stenman, O. The Importance of Ethics in Environmental Economics with a Focus on Existence Values. Environ. Resour. Econ. 1998, 11, 429-442. [CrossRef]

79. Kish, K.; Quilley, S. Wicked Dilemmas of Scale and Complexity in the Politics of Degrowth. Ecol. Econ. 2017, 142, 306-317. [CrossRef]

80. Quilley, S. Navigating the Anthropocene: Environmental Politics and Complexity in an Era of Limits. In Economics for the Anthropocene; Edward Elgar: Cheltenham, UK, 2017.

81. Quilley, S. De-Growth Is Not a Liberal Agenda: Relocalisation and the Limits to Low Energy Cosmopolitanism. Environ. Values 2013, 22, 261-285. [CrossRef]

82. Costanza, R.; d'Arge, R.; de Groot, R.; Farber, S.; Grasso, M.; Hannon, B.; Limburg, K.; Naeem, S.; O’Neill, R.V.; Paruelo, J.; et al. The Value of the World's Ecosystem Services and Natural Capital. Nature 1997, 387, 253-260. [CrossRef]

83. Martinez-Alier, J.; Kallis, G.; Veuthey, S.; Walter, M.; Temper, L. Social Metabolism, Ecological Distribution Conflicts, and Valuation Languages. Ecol. Econ. 2010, 70, 153-158. [CrossRef]

84. Dietz, R.; O'Neill, D.; Daly, H. Enough Is Enough: Building a Sustainable Economy in a World of Finite Resources; Berrett-Koehler Publishers: San Francisco, CA, USA, 2012; ISBN 978-1-60994-805-4. 
85. Fitouss, J.-P.; Sen, A.K.; Stiglitz, J.E. Mismeasuring Our Lives: Why GDP Doesn't Add up; ReadHowYouWant.com: Sydney, Austrilia, 2011; ISBN 978-1-4596-1779-7.

86. van den Bergh, J. Don't Worry, Be Happy. Altern. J. 2017, 43, 22-24.

87. Otero, I.; Farrell, K.N.; Pueyo, S.; Kallis, G.; Kehoe, L.; Haberl, H.; Plutzar, C.; Hobson, P.; García-Márquez, J.; Rodríguez-Labajos, B.; et al. Biodiversity Policy beyond Economic Growth. Conserv. Lett. 2020, 13. [CrossRef]

88. Keating, F. Selfies Linked to Narcissism, Addiction and Mental Illness, Say Scientists. International Business Times. 21 March 2014. Available online: http:/ / www.ibtimes.co.uk/selfies-linked-narcissism-addiction-mental-illness-say-scientists-1441480 (accessed on 1 February 2021).

89. Donnellan, M.B.; Trzesniewski, K.H.; Robins, R.W. An Emerging Epidemic of Narcissism or Much Ado about Nothing? J. Res. Personal. 2009, 43, 498-501. [CrossRef]

90. Twenge, J.M.; Keith Campbell, W. The Narcissism Epidemic: Living in the Age of Entitlement; Free Press: New York, NY, USA, 2010; ISBN 978-1-4165-7599-3.

91. Twenge, J.M.; Foster, J.D. Mapping the Scale of the Narcissism Epidemic: Increases in Narcissism 2002-2007 within Ethnic Groups. J. Res. Personal. 2008, 42, 1619-1622. [CrossRef]

92. Waugaman, R.M. The Narcissism Epidemic, Edited by Jean W. Twenge \& W. Keith Campbell. Psychiatry Interpers. Biol. Process. 2011, 74, 166-169. [CrossRef]

93. Naess, A. Ecology, Community and Lifestyle: Outline of an Ecosophy; Cambridge University Press: Cambridge, MA, USA, 1990; ISBN 978-0-521-34873-7.

94. Wilson, D.S. Evolution for Everyone: How Darwin's Theory Can Change the Way We Think about Our Lives, Reprint edition; Delta: New York, NY, USA, 2007; ISBN 978-0-385-34092-2.

95. Wilson, E.O. The Social Conquest of Earth, Reprint edition; Liveright: New York, NY, USA, 2013; ISBN 978-0-87140-363-6.

96. Pörtner, H.-O.; Giomi, F. Nothing in Experimental Biology Makes Sense except in the Light of Ecology and EvolutionCorrespondence on J. Exp. Biol. 216, 2771-2782. J. Exp. Biol. 2013, 216, 4494-4495. [CrossRef] [PubMed]

97. Wilson, E.O. The Sociobiology Debate: Readings on Ethical and Scientific Issues, 1st ed.; Caplan, A.L., Ed.; Harper \& Row: New York, NY, USA, 1978; ISBN 978-0-06-010633-1.

98. Sober, P.E.; Wilson, P.D.S.; Wilson, D.S. Unto Others: The Evolution and Psychology of Unselfish Behavior, New edition; Harvard University Press: Cambridge, MA, USA, 1999; ISBN 978-0-674-93047-6.

99. Sánchez-Villagra, M.R.; van Schaik, C.P. Evaluating the Self-Domestication Hypothesis of Human Evolution. Evol. Anthropol. Issues News Rev. 2019, 28, 133-143. [CrossRef]

100. Harari, Y.N. Sapiens: A Brief History of Humankind, Illustrated edition; Harper: New York, NY, USA, 2015; ISBN 978-0-06-231609-7.

101. Lenton, T.M.; Williams, H.T.P. On the Origin of Planetary-Scale Tipping Points. Trends Ecol. Evol. 2013, 28, 380-382. [CrossRef]

102. Liu, J.; Dietz, T.; Carpenter, S.R.; Alberti, M.; Folke, C.; Moran, E.; Pell, A.N.; Deadman, P.; Kratz, T.; Lubchenco, J.; et al. Complexity of Coupled Human and Natural Systems. Science 2007, 317, 1513-1516. [CrossRef]

103. Steffen, W.; Richardson, K.; Rockström, J.; Cornell, S.E.; Fetzer, I.; Bennett, E.M.; Biggs, R.; Carpenter, S.R.; de Vries, W.; de Wit, C.A.; et al. Planetary Boundaries: Guiding Human Development on a Changing Planet. Science 2015, 347. [CrossRef]

104. Raworth, K. Doughnut Economics: Seven Ways to Think Like a 21st-Century Economist; Chelsea Green Publishing: White River Junction, VT, USA, 2017; ISBN 978-1-60358-674-0.

105. Boffey, D. Amsterdam to Embrace "Doughnut" Model to Mend Post-Coronavirus Economy. Available online: http:/ / www.theguardian. com/world/2020/apr/08/amsterdam-doughnut-model-mend-post-coronavirus-economy (accessed on 26 January 2021).

106. Ruder, S.-L.; Sanniti, S.R. Transcending the Learned Ignorance of Predatory Ontologies: A Research Agenda for an EcofeministInformed Ecological Economics. Sustainability 2019, 11, 1479. [CrossRef]

107. Hensher, M.; Kish, K.; Farley, J.; Quilley, S.; Zywert, K. Open Knowledge Commons versus Privatized Gain in a Fractured Information Ecology: Lessons from COVID-19 for the Future of Sustainability. Glob. Sustain. 2020, 3. [CrossRef]

108. Gowdy, J.; Krall, L. The Ultrasocial Origin of the Anthropocene. Ecol. Econ. 2013, 95, 137-147. [CrossRef]

109. Gowdy, J.; Krall, L. The Economic Origins of Ultrasociality. Behav. Brain Sci. 2016, 39. [CrossRef]

110. Original Tribal Names. Available online: http:/ / www.native-languages.org/original.htm (accessed on 1 December 2020).

111. Graeber, D. Debt: The First 5000 Years, Reprint edition; Melville House: Brooklyn, NY, USA, 2012; ISBN 978-1-61219-129-4.

112. Allen, T.F.H.; Tainter, J.A.; Pires, J.C.; Hoekstra, T.W. Dragnet Ecology—“Just the Facts, Ma'am”: The Privilege of Science in a Postmodern WorldScience of Intrinsic Quality Needs Narratives with Explicit Values—Not Just Facts—Particularly as It Faces Multiple-Level Complexity in Advising on Environmental Policy, Such as Planning for Energy Futures. BioScience 2001, 51, 475-485. [CrossRef]

113. Hoffman, D.D. The Case against Reality: Why Evolution Hid the Truth from Our Eyes, Illustrated edition; WW Norton: New York, NY, USA, 2019; ISBN 978-0-393-25469-3.

114. Falk, A.E. Darwin's Cathedral: Evolution, Religion, and the Nature of Society. By David Sloan Wilson. Q. Rev. Biol. 2003, 78, 74-75. [CrossRef]

115. Haidt, J. The Righteous Mind: Why Good People Are Divided by Politics and Religion, Illustrated edition; Vintage: New York, NY, 2013; ISBN 978-0-307-45577-2.

116. Soros, G. Fallibility, Reflexivity, and the Human Uncertainty Principle. J. Econ. Methodol. 2013, 20, 309-329. [CrossRef] 